\title{
SNHS SANCTUARIES
}

\section{STAN SHADICK, 3F - 1800 Main Street, Saskatoon, Saskatchewan. S7H 4B3}

The centennial of the Last Mountain Lake Bird Sanctuary occurs on 8 June 1987. This event has prompted Canadian naturalists to focus on 1987 as the Centennial of wildlife conservation.

Although the Last Mountain Lake Sanctuary is now famous across Canada, few people are aware of two other sanctuaries in Saskatchewan, namely the Maurice Street Sanctuary near Nipawin and the Prairie Dog Sanctuary near Val Marie. Both of these sanctuaries were established and are currently leased by the Saskatchewan Natural History Society (SNHS).

\section{Maurice Street Wildlife Sanctuary}

Maurice Street was a keen bird watcher who lived in Nipawin and co-authored the SNHS Special Publication The birds of the Saskatchewan River (1959). As a memorial to Maurice Street the SNHS leased a half-section to be maintained as a wildlife sanctuary. ${ }^{1}$ The sanctuary is located on the banks of the Saskatchewan River northeast of Nipawin. It contains all of the portion of Section 1-52-14-W2 which lies to the east of the Saskatchewan River and all that portion of the south half of Section 12-52-14-W2 which lies to the south of the Saskatchewan. ${ }^{2}$

The sanctuary lands are heavily wooded with Jack Pine but a wide variety of other habitats are found nearby. Unfortunately there are no known published bird, mammal or flora lists for this sanctuary. (A regional list of 103 bird species was identified during the 1968 SNHS Summer Meat and was published in the SNHS Newsletter \#20, August 1968. ${ }^{5}$ )

As the 21-year lease on this property apparently comes up for renewal next year the SNHS executive will need to consider future plans for this sanctuary. Individual SNHS members could help by visiting the sanctuary this summer and reporting their observations and comments to the author or any member of the executive. If we neglect this sanctuary we may lose the right to renew its lease.

The road to the sanctuary is marked by a sign on Highway 55 east of Nipawin. The route to the sanctuary over gravel and dirt roads is shown on the map. Be sure to bring insect repellent.

\section{Prairie Dog Sanctuary}

In 1965 The Saskatchewan Natural History Society acquired the lease to a quarter section (NE 23-2-13-W3) in the Frenchman River Valley se of Val Marie. This sanctuary was estabished to protect a colony of 400 Black-tailed Prairie Dogs, one of the last large prairie dog towns in Canada. ${ }^{4}$ On 14 June 1969 a cairn was dedicated on the occasion of the SNHS Summer Meet held there. ${ }^{3}$

Visitors arriving at the site should remain in their vehicle in order to obtain the best view of the prairie dogs. When one leaves the vehicle the prairie dogs quickly hide underground.

In addition to prairie dogs, visitors should look for Richardson's Ground Squirrels and possibly rattlesnakes or antelope. Some of the birds that may be seen in the area include Horned Lark, Western Meadowlark, Long-billed Curlew, Burrowing Owl, Ferruginous and Swainson's hawks, Golden Eagle, Prairie Falcon and Killdeer. There is also a published sighting by B. Peart and J.G. Woods of eight Mountain Plover seen 22 September 1977; this is an extremely rare species in Canada. ${ }^{6}$ 
mie access to the sanctuary is over a 2-mile dirt trail which starts west of the Kornfield ranch south of Val Marie. This trail should only be used when dry. If you should arrive after a recent rain it is recommended that you visit one of the other prairie dog towns marked on the map which are accessible from a gravel road.

1 ANONYMOUS. 1967. Maurice Street Wildlife Sanctuary. Blue Jay 25:156.

2 ANONYMOUS. 1968. Summer meeting, 1968. Blue Jay 26:163.

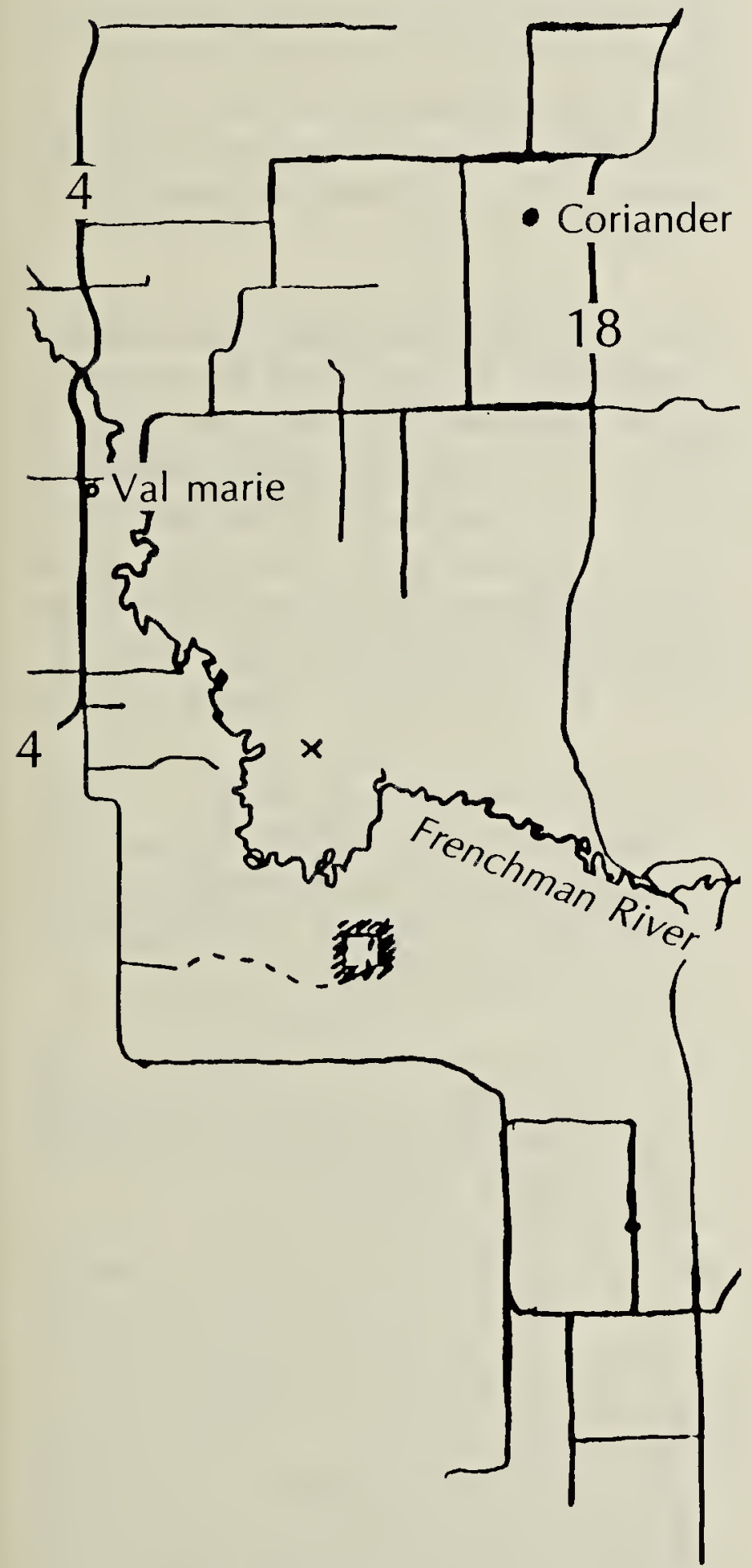

3 ANONYMOUS. 1969. SNHS Summer meeting, 1969. Blue Jay 27:180.

4 LEDINGHAM, G. 1965. Prairie dogs and ferrets editorial. Blue Jay 23(1): front cover.

5 McLAUGHLIN, R. 1968. Summer meet. SNHS Newsletter 20.

6 PEART, B. and J.G. WOODS. 1980. Mountain Plover observation near Val Marie. Blue Jay 38:41.

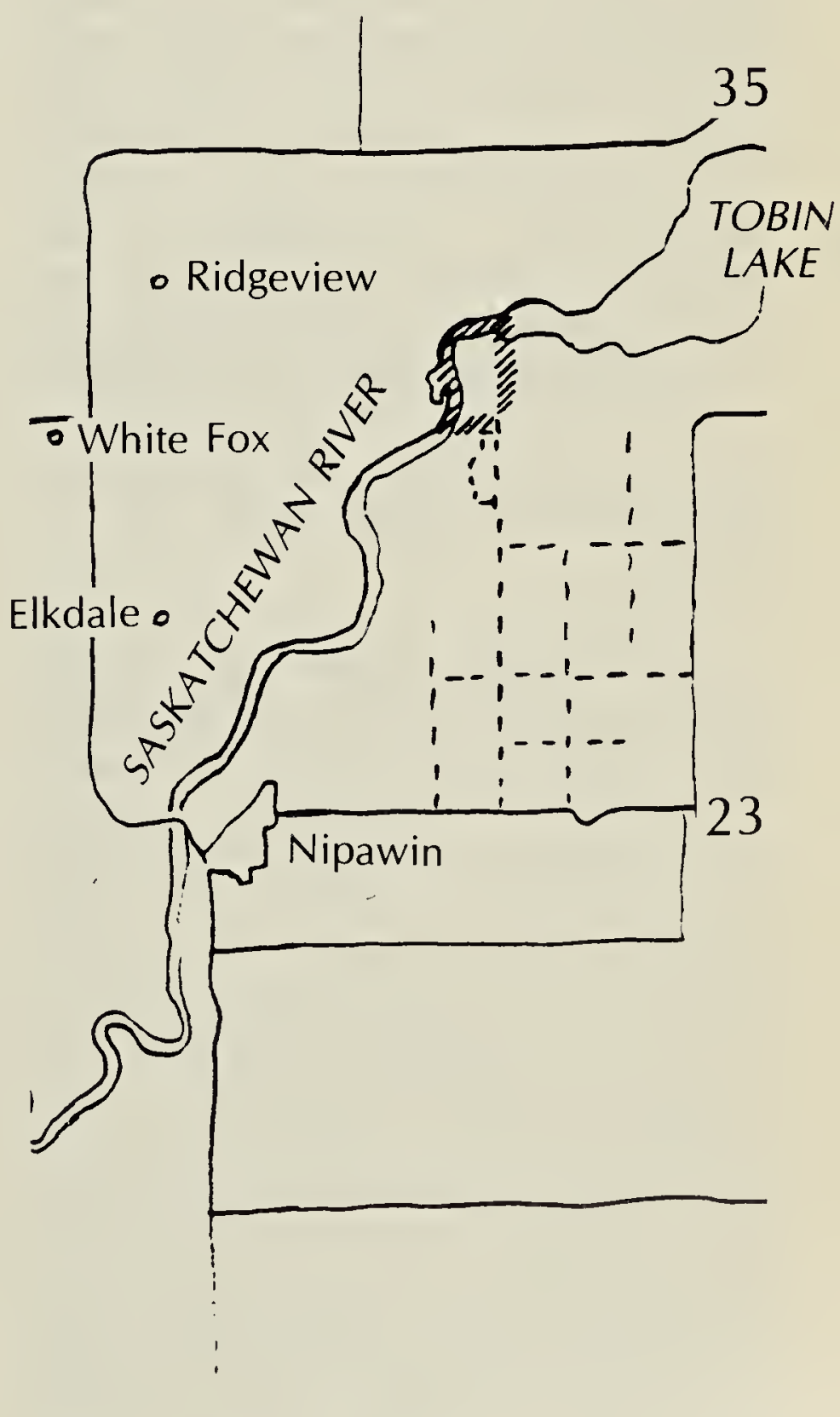

Maurice Street Sanctuary.

Prairie Dog Sanctuary.



